
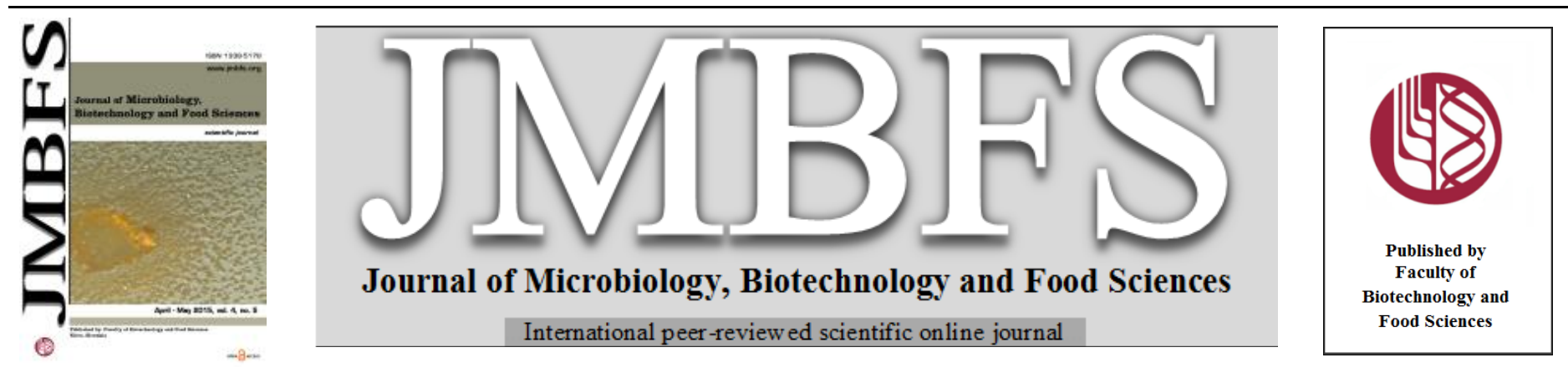

\title{
IN VITRO MASS-SCREENING OF LACTIC ACID BACTERIA AS POTENTIAL BIOSORBENTS OF CESIUM AND STRONTIUM IONS
}

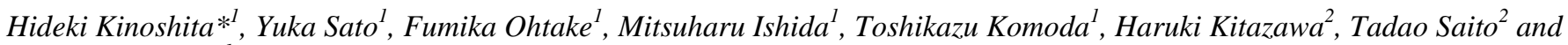 \\ Kazuhiko Kimura ${ }^{l}$
}

Address(es): Hideki Kinoshita,

${ }^{1}$ Miyagi University, Department of Food Management, School of Food, Agricultural and Environmental Sciences, 2-2-1 Hatatate, Sendai, Miyagi 982-0215, Japan. Phone: +81-22-245-1382.

${ }^{2}$ Tohoku University, Graduate School of Agricultural Science, 1-1 Tsutsumidori-Amamiyamachi, Sendai, Miyagi 981-8555, Japan.

*Corresponding author: kinoshih@myu.ac.jp

doi: 10.15414/jmbfs.2015.4.5.383-386

ARTICLE INFO

Received 19.7. 2014

Revised 3. 9. 2014

Accepted 14. 1. 2015

Published 1. 4. 2015

Regular article

OPEN OACCESS

\begin{abstract}
Many radionuclides were scattered by the explosion at the Fukushima Daiichi Nuclear Power Station. We examined whether lactic acid bacteria (LAB) can sorb cesium ions $\left(\mathrm{Cs}^{+}\right)$and strontium ions $\left(\mathrm{Sr}^{2+}\right)$ for radioprotection. Many strains showed biosorption to $\mathrm{Cs}^{+}$and $\mathrm{Sr}^{2+}$ using an in vitro mass-screening although each strain showed different sorption. We selected MYU 111, MYU 758, and MYU 759 strains that showed especially high biosorption to $\mathrm{Cs}^{+}$and/or $\mathrm{Sr}^{2+}$. MYU 111 was identified as Lactobacillus plantarum, and MYU 758 and 759 were Pediococcus pentosaceus. The selected strains tended to show higher biosorption when using the buffer method compared

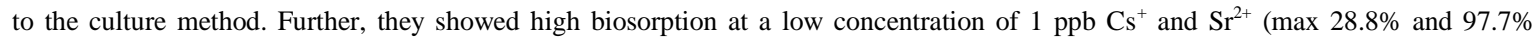
sorption, respectively). This is the first study where lactic acid bacteria are shown to have biosorption of $\mathrm{Cs}^{+}$and $\mathrm{Sr}^{2+}$.
\end{abstract}

Keywords: Lactic acid bacteria, cesium, strontium, biosorption

\section{INTRODUCTION}

Many radionuclides such as iodine (I), cesium (Cs), and strontium (Sr) were scattered by the explosion at the Fukushima Daiichi Nuclear Power Station caused by the Great East Japan Earthquake on March 11, 2011. Steinhauser et al. (2014) estimated a total source term of 520 (340-780) peta-becquerels (PBq) or about one-tenth the radiation released during the 1986 Chernobyl disaster. The radiation has been released to soil, sea and river widely around Fukushima (Kinoshita et al., 2011, Hirose, 2012, Steinhauser et al., 2013, Steinhauser, 2014), and has polluted water and food such as crops, animal products, fish and seafood (Hamada et al., 2012, Hamada \& Ogino, 2012, Merz et al., 2013, Yamamoto et al., 2014). Especially, the exposure to radionuclides such as ${ }^{134} \mathrm{Cs}$, ${ }^{137} \mathrm{Cs}$, and ${ }^{90} \mathrm{Sr}$ may lead to long term ill health effects. Many reports show the effects of low level radiation. A comprehensive review of available biological and biophysical data supports a linear no-threshold (LNT) risk model where the risk of cancer occurs in a linear fashion at lower doses without a threshold (NAS/NRC, 2006, Royal, 2008). Romanenko et al. (2012) reported that exposure to low doses and to low dose-rates of radiation from post-Chornobyl cleanup work was associated with a significant increase of risk in leukemia. Nzabarushimana et al. (2014) report exposure to low doses of ${ }^{56} \mathrm{Fe}$ causes an increased in chemokine $\mathrm{Ccl} 3$, and interleukin $\mathrm{Il}-4$ expression; and interloikine and global DNA hypermethylation in the mouse lung. Taira et al. (2014) reported forewing size reduction, growth retardation, high mortality rates, and high abnormality rates in pale grass blue butterflies, Zizeeria maha, captured from the Fukushima area.

Lactic acid bacteria (LAB) have biosorption ability for heavy metals. Recently, we reported that $\mathrm{LAB}$ showed high biosorption of cadmium ion $\left(\mathrm{Cd}^{2+}\right)$ and mercury ion $\left(\mathrm{Hg}^{2+}\right)$ (Kinoshita et al., 2013). Weissella viridescens MYU 205 showed high biosorption, and it's cell surface proteins bound $\mathrm{Hg}^{2+}$. Further reports show LABs have biosorption ability to various heavy metals such as $\mathrm{Cd}^{2+}$, $\mathrm{Pb}^{2+}$, and $\mathrm{Cu}^{2+}$ (Ibrahim et al., 2006, Schut et al., 2011, Bhakta et al., 2012). Recently, Sasaki et al. (2012a) reported about $90 \%$ of the radioactive Cs in the sediment mud of a school's swimming pool in Fukushima was removed using the alginate-immobilized photosynthetic bacterium Rhodobacter sphaeroides SSI. Therefore, we speculated LABs might be able to absorb and/or adsorb $\mathrm{Cs}^{+}$and $\mathrm{Sr}^{2+}$. One of the primary features of LABs is high safety. People are eating many LAB strains with food, especially fermented food, and therefore LABs are GRAS organisms (Stiles \& Holzapfel, 1997, Feord, 2002). Oral ingestion of LAB showing high biosorption of $\mathrm{Cs}^{+}$and $\mathrm{Sr}^{2+}$ may prevent the absorption of $\mathrm{Cs}^{+}$and $\mathrm{Sr}^{2+}$ into the body, and may efficiently discharge them from the body via feces. Thus, our aims were to examine the $\mathrm{Cs}^{+}$and $\mathrm{Sr}^{2+}$ biosorption ability of LAB derived from food using an in vitro mass-screening.

\section{MATERIALS AND METHODS}

Seventy-seven strains of lactic acid bacteria were isolated from various foods, e.g., rice, bovine and porcine intestines (called Horumon in Japan), Japanese pickles, Japanese Amazake, kimchee, and yogurt. Bacterial strains were propagated twice at $37^{\circ} \mathrm{C}$ for $24 \mathrm{~h}$ in MRS broth with $2 \%(\mathrm{v} / \mathrm{v})$ inoculum before the experiments.

Non-radioactive $\mathrm{Cs}^{+}$and $\mathrm{Sr}^{2+}$ were used in this study. The mass-screening of LAB having either $\mathrm{Cs}^{+}$or $\mathrm{Sr}^{2+}$ binding ability was performed using the culture method. MRS broth (Difco Laboratories, Detroit, MI) containing $10 \mathrm{ppm} \mathrm{Cs}^{+} \mathrm{or} \mathrm{Sr}^{2+}$ was prepared using a 1,000 ppm $\mathrm{Cs}$ standard $\left(\mathrm{CsNO}_{3}\right.$ in $\left.2-3 \% \mathrm{HNO}_{3}\right)(\mathrm{Merck}$, Darmstadt, Germany) or 1,000 ppm Sr standard $\left(\mathrm{Sr}\left(\mathrm{NO}_{3}\right)_{2}\right.$ in $\left.2-3 \% \mathrm{HNO}_{3}\right)$ (Merck, Darmstadt, Germany), respectively. Tests with ions were performed separately. Seventy-seven LAB strains isolated from food were propagated at $37^{\circ} \mathrm{C}$ for $24 \mathrm{~h}$ in $10 \mathrm{ml}$ of MRS broth containing either $10 \mathrm{ppm} \mathrm{Cs}^{+}$or $10 \mathrm{ppm}$ $\mathrm{Sr}^{2+}$. Bacterial cells after culture were washed three times with sterile distilled water and the wet weight of the cells was measured. The pellets were suspended in $10 \% \mathrm{HNO}_{3}$ and heated at $105^{\circ} \mathrm{C}$ for $2 \mathrm{~h}$. A few drops of hydrogen peroxide $\left(\mathrm{H}_{2} \mathrm{O}_{2}\right)$ were added where the liquid was completely vaporized to lyse and degrade the cells. The remaining $\mathrm{Cs}^{+}$or $\mathrm{Sr}^{2+}$ was diluted with $10 \mathrm{ml}$ of $5 \% \mathrm{HNO}_{3}$ and 5,000 ppm (final concentration) potassium nitrate solution (Merck, Darmstadt, Germany) was added; and the concentrations were measured using an atomic absorption spectrophotometer (AAS) SpectrAA-55 (Agilent Technologies, Santa Clara, CA).

The $\mathrm{Cs}^{+}$or $\mathrm{Sr}^{2+}$ biosorption by selected strains was tested in buffer (the buffer method). Bacterial cells cultured for $24 \mathrm{~h}$ were washed three times with distilled water, and the pellet was measured with the same weight as the culture method. The pellet was suspended in $10 \mathrm{ml}$ of $10 \mathrm{mmol} / \mathrm{L}$ sodium citrate buffer $(\mathrm{pH} \mathrm{6.0})$ containing $10 \mathrm{ppm} \mathrm{Cs}^{+}$or $\mathrm{Sr}^{2+}$, and was incubated at $37^{\circ} \mathrm{C}$ for 1 or $24 \mathrm{~h}$. After incubation, the suspension was centrifuged $\left(8,000 \mathrm{rpm}, 10 \mathrm{~min}, 4^{\circ} \mathrm{C}\right)$ and the $\mathrm{Cs}^{+}$ or $\mathrm{Sr}^{2+}$ concentration of the supernatant with 5,000 ppm (final concentration) potassium nitrate solution added was measured using AAS. Buffer containing no 
bacteria was used as a negative control (NC). The amount of biosorption $(\mu \mathrm{g})$ was calculated by subtracting the sample value from the control value.

The $\mathrm{Cs}^{+}$or $\mathrm{Sr}^{2+}$ biosorption assay at low concentrations was performed using MilliQ water containing $1 \mathrm{ppb} \mathrm{Cs}^{+}$or $\mathrm{Sr}^{2+}$ following the same procedure as the buffer method. The bacterial cells cultured for $24 \mathrm{~h}$ were washed three times with MilliQ water, and $0.05 \mathrm{~g}$ of the pellet was suspended with $5 \mathrm{ml}$ of MilliQ water containing $1 \mathrm{ppb} \mathrm{Cs}^{+}$or $\mathrm{Sr}^{2+}$; and was incubated at $37^{\circ} \mathrm{C}$ for $1 \mathrm{~h}$. After incubation, the bacterial cells were centrifuged $\left(5,000 \mathrm{rpm}, 10 \mathrm{~min}, 4^{\circ} \mathrm{C}\right)$; and the $\mathrm{Cs}^{+} \mathrm{or} \mathrm{Sr}^{2+}$ concentration of the supernatant was measured using an inductively coupled plasma mass spectrometer (ICP-MS) ELAN DRC-e (Perkin Elmer SCIEX, Boston, MA). $\mathrm{Cs}^{+}$or $\mathrm{Sr}^{2+}$ solution (1 ppb) containing no bacteria was used as the control. The rate of biosorption (\%) was calculated by subtracting the sample value from the control value.

The assays were performed in triplicate and all data were reported as the mean \pm SD. The data was assessed using analysis of variance (ANOVA). When ANOVA was significant, the significance of differences was determined using the twotailed t-test with Bonferroni adjustments.

\section{RESULTS AND DISCUSSION}

\section{The mass-screening of LAB show $\mathrm{Cs}^{+}$and/or $\mathrm{Sr}^{2+}$ biosorption}

Many strains showed biosorption of either $\mathrm{Cs}^{+}$or $\mathrm{Sr}^{2+}$ using the culture massscreening method although each strain showed different sorptions. The average $\mathrm{Cs}^{+}$biosorption in 77 strains was $0.89 \pm 0.81 \mu \mathrm{g}$ showing $0.9 \%$ of total $\mathrm{Cs}^{+}$ MYU 758 showed the highest at $2.4 \pm 0.082 \mu \mathrm{g}$; and the second highest was MYU 759 at $2.4 \pm 0.082 \mu \mathrm{g}$. The average $\mathrm{Sr}^{2+}$ biosorption was $0.76 \pm 0.43 \mu \mathrm{g}$ showing $0.8 \%$ of the total $\mathrm{Sr}^{2+}$. MYU 759 showing the second highest in $\mathrm{Cs}^{+}$ biosorption showed the highest $\mathrm{Sr}^{2+}$ sorption at $2.1 \pm 0.082 \mu \mathrm{g}$. MYU 111 showed $1.9 \pm 0.00 \mu \mathrm{g}$. This suggests LABs may be potential $\mathrm{Cs}^{+}$and $\mathrm{Sr}^{2+}$ sorbents. Because the chemical properties of stable isotopes and radioisotopes are the same, our data suggests LAB can also sorb ${ }^{134} \mathrm{Cs},{ }^{137} \mathrm{Cs}$, and ${ }^{90} \mathrm{~S}$ radioisotopes. The three strains were identified using the Gram stain, catalase test and 16S rDNA sequencing analysis. MYU 111 isolated from pickled Japanese radish was identified as Lactobacillus plantarum, and MYU 758 and 759 isolated from rice were Pediococcus pentosaceus. We selected these three strains showing high biosorption for further experiments

\section{Comparison of the culture method and the buffer method}

Figure 1 shows the data for $\mathrm{Cs}^{+}$or $\mathrm{Sr}^{2+}$ biosorption using the culture and the buffer methods. $\mathrm{Cs}^{+}$biosorption using the buffer method incubating for $1 \mathrm{~h}$ was significantly higher than the culture method for L. plantarum MYU 111 and $P$. pentosaceus MYU $758(p<0.01)$ although no significant difference was observed in $P$. pentosaceus MYU 759 comparing the two methods. The $\mathrm{Cs}^{+}$biosorption using the buffer method incubating for $24 \mathrm{~h}$ was lower than the buffer method incubating for $1 \mathrm{~h}$; and had a significant difference at $24 \mathrm{~h}$ compared to the culture method (none for MYU 758). $\mathrm{Cs}^{+}$may be incorporated into the cells because $\mathrm{Cs}^{+}$behaves like $\mathrm{K}^{+}$. A portion of the sorbed $\mathrm{Cs}^{+}$may be quenched by 24 h.

$\mathrm{Sr}^{2+}$ biosorption using the buffer method incubating for $1 \mathrm{~h}$ and $24 \mathrm{~h}$ was significantly higher than the culture method in all selected strains $(p<0.01)$ Especially, $P$. pentosaceus MYU 759 showed the highest biosorption at $13.67 \pm$ $0.05 \mu \mathrm{g}$, about $14 \%$ of the total $\mathrm{Sr}^{2+}$. $\mathrm{Sr}^{2+}$ may be bound to cell surface proteins because $\mathrm{Sr}^{2+}$ behaves like $\mathrm{Ca}^{2+}$ whose concentration is lower inside a cell causing a gradient. The difference in the amount of biosorption using the buffer method and the culture method may be related to competitive ions such as $\mathrm{Na}^{+}, \mathrm{K}^{+}, \mathrm{Ca}^{2+}$, and $\mathrm{Mg}^{2+}$. And/or, the $\mathrm{pH}$ may influence sorption because $\mathrm{pH}$ becomes lower using the culture method after $24 \mathrm{~h}$. The competitive ions and/or the low $\mathrm{pH}$ may have more strongly inhibited biosorption because the $\mathrm{Sr}^{2+}$ biosorption was higher than the $\mathrm{Cs}^{+}$biosorption using the buffer method. Halttunen et al. (2008) reported $\mathrm{Cd}^{2+}$ biosorption significantly decreased when using competitive ions such as $\mathrm{Mg}^{2+}, \mathrm{Ca}^{2+}, \mathrm{Fe}^{2+}, \mathrm{Zn}^{2+}$, and $\mathrm{Pb}^{2+}$ in L. fermentum ME3 and Bifidobacterium longum 46. When we measured the concentrations of metal ions in MRS broth, MRS broth contained 1,900 ppm Na${ }^{+}, 1,800 \mathrm{ppm} \mathrm{K}^{+}, 50 \mathrm{ppm} \mathrm{Mg}^{2+}$, and $70 \mathrm{ppm}$ $\mathrm{Ca}^{2+}$. The buffer contains about $566 \mathrm{ppm} \mathrm{Na}$. In our previous study using $\mathrm{Cd}^{2+}$ the amount of biosorption tended to be lower when the pH was low (Kinoshita $e$ al., 2013). Comparable data are reported by others. Volesky et al. (1993) reported $\mathrm{Cd}^{2+}$ biosorption by Saccharomyces cerevisiae was inhibited by protons under acidic conditions. He and Tebo (1998) reported that $\mathrm{pH}$-dependent copper biosorption with spores of a marine Bacillus sp. The amount of biosorption decreased by as much as $90 \%$ at $\mathrm{pH} 4.0$ as compared to $\mathrm{pH} 8.0$. The cell surface proteins of LAB are positively charged below the isoelectric point and may have difficulty adsorbing $\mathrm{Sr}^{2+}$ at low $\mathrm{pH}$.
A

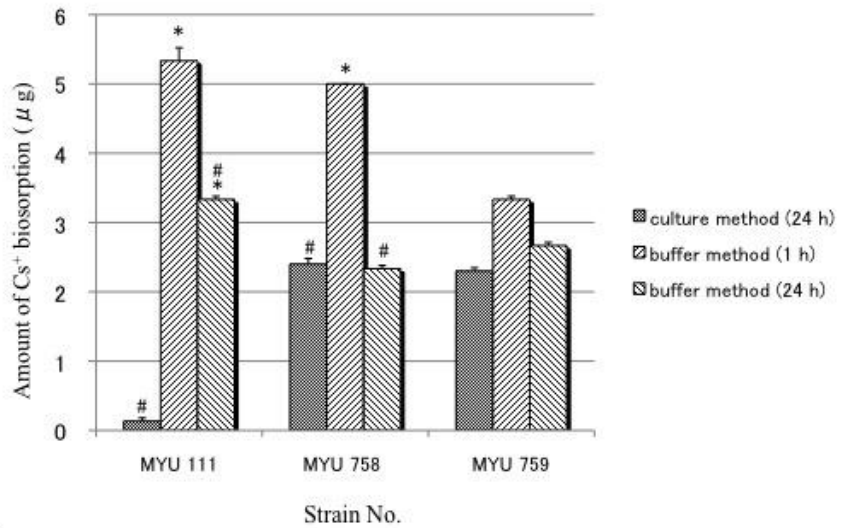

B

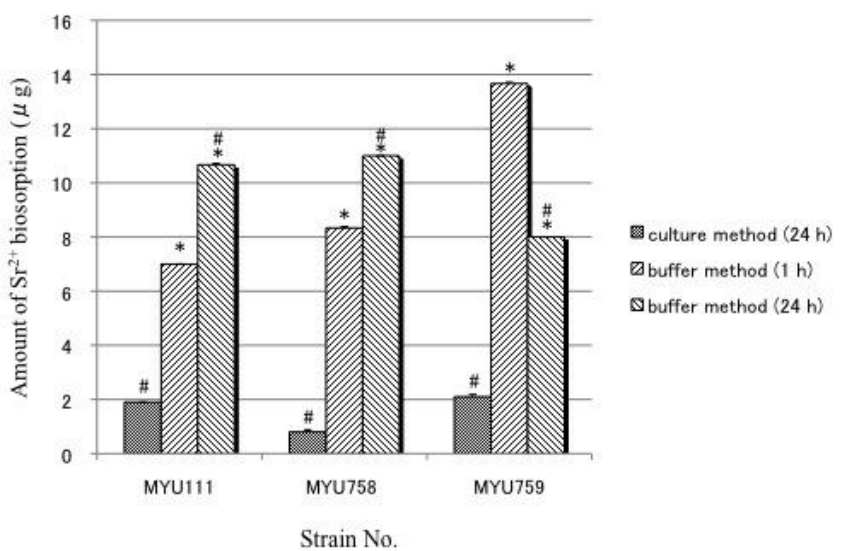

Figure 1 Comparison of $\mathrm{Cs}^{+}(\mathrm{A})$ and $\mathrm{Sr}^{2+}$ (B) biosorption using the culture and the buffer method.

Using the culture method, the bacterial cells were propagated at $37^{\circ} \mathrm{C}$ for $24 \mathrm{~h}$ in MRS broth containing $10 \mathrm{ppm} \mathrm{Cs}^{+}$or $\mathrm{Sr}^{2+}$. After washing with sterile distilled water, the $\mathrm{Cs}^{+}$or $\mathrm{Sr}^{2+}$ concentration of the pellets was measured $(\mathrm{n}=3)$.

Using the buffer method, the bacterial cells cultured for $24 \mathrm{~h}$ were washed three times with distilled water, the pellet was suspended with $10 \mathrm{mmol} / \mathrm{L}$ sodium citrate buffer ( $\mathrm{pH}$ 6.0) containing $10 \mathrm{ppm} \mathrm{Cs}^{+} \mathrm{or} \mathrm{Sr}^{2+}$, and was incubated at $37^{\circ} \mathrm{C}$ for 1 or $24 \mathrm{~h}$. After incubation, the suspension was centrifuged and the $\mathrm{Cs}^{+} \mathrm{Or} \mathrm{Sr}^{2+}$ concentration of the supernatant was measured $(n=3)$. The amount of biosorption $(\mu \mathrm{g})$ was calculated by subtracting the sample value from the control value.

The same weight of bacteria was used in both methods.

*: Significant difference compared to the culture method $(p<0.01)$.

\#: Significant difference compared at $1 \mathrm{~h}$ to the buffer method $(p<0.01)$.

\section{Biosorption assay at low concentrations of $\mathrm{Cs}^{+}$or $\mathrm{Sr}^{2+}$}

LABs are required to show biosorption at low concentrations because people may eat food containing very low concentrations of radioactive $\mathrm{Cs}^{+}$and $\mathrm{Sr}^{2+}$. Figure 2 shows the data for the biosorption at $1 \mathrm{ppb} \mathrm{Cs}^{+}$or $\mathrm{Sr}^{2+}$. The percent $\mathrm{Cs}^{+}$ biosorption was $0 \%$ in MYU $111,25.7 \pm 1.6 \%$ in MYU 758 , and $28.8 \pm 2.9 \%$ in MYU759. The percent $\mathrm{Sr}^{2+}$ biosorption was $78.0 \pm 0.3 \%$ in MYU $111,97.7 \pm$ $0.4 \%$ in MYU 758, and $95.6 \pm 0.2 \%$ in MYU759. These selected strains showed high biosorption at low concentration of $\mathrm{Cs}^{+}$and $\mathrm{Sr}^{2+}$. Further work is needed to show biosorption of radioactive $\mathrm{Cs}^{+}$and $\mathrm{Sr}^{2+}$ in the presence of a large amount of competitive ions such as $\mathrm{Na}^{+}, \mathrm{K}^{+}, \mathrm{Ca}^{2+}$, and $\mathrm{Mg}^{2+}$, and non-radioactive $\mathrm{Cs}^{+}$and $\mathrm{Sr}^{2+}$ naturally contained in food; and further if LABs can exclude radioactive $\mathrm{Cs}^{+}$ and $\mathrm{Sr}^{2+}$ in human intestinal feces. The LAB showing high biosorption of $\mathrm{Hg}^{2+}$ can prevent uptake of $\mathrm{Hg}^{2+}$ into Caco-2 cells in our studies (unpublished data), although, further investigation is needed. 


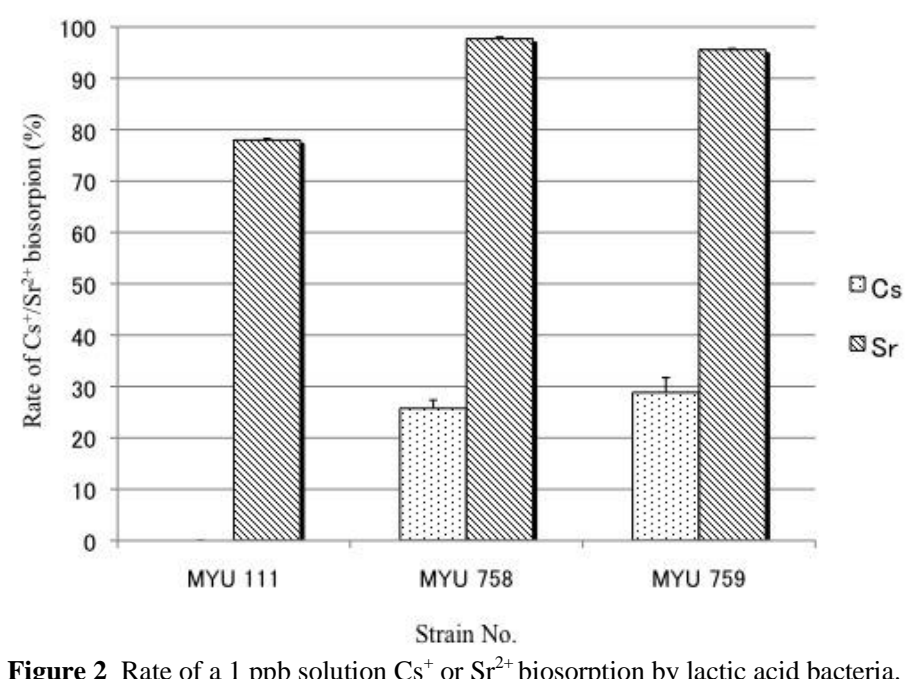

The bacterial cells cultured for $24 \mathrm{~h}$ were washed three times with MilliQ water; $0.05 \mathrm{~g}$ of the pellet was suspended with $5 \mathrm{ml}$ of MilliQ water containing $1 \mathrm{ppb}$ $\mathrm{Cs}^{+}$or $\mathrm{Sr}^{2+}$; and was incubated at $37^{\circ} \mathrm{C}$ for $1 \mathrm{~h}$. After incubation, the bacterial cells were centrifuged $\left(5,000 \mathrm{rpm}, 10 \mathrm{~min}, 4^{\circ} \mathrm{C}\right)$; and the $\mathrm{Cs}^{+}$and $\mathrm{Sr}^{2+}$ concentration of the supernatant was measured using ICP-MS $(n=3)$, respectively. The rate of biosorption $(\%)$ was calculated by subtracting the sample value from the control value.

\section{Possibility of radio protection using $\mathrm{LAB}$}

Some reports show the radio protective effects of $\mathrm{LAB}$ and yeast. Nomoto et al. (1991) report a single subcutaneous dose of heat-killed L. casei YIT 9018 (LC 9018) was highly radio protective when given shortly after irradiation in mice. Tsuneoka et al. (1994) reported a single dose of LC 9018 was radio protective, even when administered as late as $30 \mathrm{~h}$ after or as early as 7 days before irradiation. The extent of the radio protective effect was similar when LC 9018 was administered during the period from 2 days before irradiation to $9 \mathrm{~h}$ after irradiation, although the pre-irradiation treatment was slightly more effective than the post-irradiation treatment. Ciorba et al. (2012) reported orally administered $L$. rhamnosus GG (LGG) and its conditioned medium protected the murine small intestinal epithelium from radiation injury. LGG-mediated radio protection is dependent on MyD88, TLR-2, and COX-2, and occurs without significantly altering the bacterial family composition of the small intestine. Administering LGG did not change the COX-2 levels; however it results in a repositioning of COX-2-expressing mesenchymal stem cells of the lamina propria from the villi to the crypt region. Anzai et al. (2008) reported radio protection of mice using intraperitoneal administration of $\mathrm{Zn}-, \mathrm{Mn}-, \mathrm{Cu}-$, or Se-containing heat-treated $S$. serevisiae. When mineral-yeasts were administered immediately after irradiation, the survival rate was higher where $\mathrm{Zn}$ - or $\mathrm{Cu}$-yeast showed the highest rate (more than $90 \%$ ). These facts show the possibility of lowering the internal exposure using LABs; however further study in long-term irradiation at low doses is needed because these previous studies were performed at lethal doses. Further, alginate-immobilized photosynthetic bacterium, Rhodobacter sphaeroides SSI removed about $90 \%$ of the radioactive Cs in the sediment mud of a school's swimming pool in Fukushima, Japan (Sasaki et al., 2012a) and the anaerobic digestion and lactic acid fermentation by lactic acid bacteria supported removal of Cs from soil (Sasaki et al., 2012b). Here, we showed the $\mathrm{Cs}^{+}$and $\mathrm{Sr}^{2+}$ biosorption ability of LAB. In addition, LABs properties, such as activation of an immune function (Perdigón et al., 2002), prevention of cancer (Lim et al., 2002)., and anti-oxidation (Yamamoto et al., 2002) may be helpful for radiation protection.

\section{CONCLUSION}

It is important to prevent the absorption of $\mathrm{Cs}^{+}$and $\mathrm{Sr}^{2+}$ into the body because they accumulate in muscle (Fukuda et al., 2013) and bone (Dahl et al., 2001), respectively, during long-term radiation exposure. In this study, we tested the biosorption ability of $77 \mathrm{LABs}$ and found LABs showed biosorption of $\mathrm{Cs}^{+}$and $\mathrm{Sr}^{2+}$. This is the first study where LABs were shown to biosorp $\mathrm{Cs}^{+}$and $\mathrm{Sr}^{2+}$. We believe oral ingestion of $\mathrm{LAB}$ showing high biosorption of $\mathrm{Cs}^{+}$and $\mathrm{Sr}^{2+}$ can prevent the absorption of $\mathrm{Cs}^{+}$and $\mathrm{Sr}^{2+}$ into the body, and may be discharged via feces from the body efficiently. This study is the first step to attempt lowering the internal radiation exposure using using LABs.

Acknowledgements: This study was financially supported by a grant from Miyagi University (2011-2012).

\section{REFERENCES}

Anzai K, Ikota N, Ueno M, Nyui M, Kagiya TV. 2008. Heat-treated mineralyeast as a potent post-irradiation radioprotector. Journal of Radiation Research 49, 425-430. http://dx.doi.org/10.1269/jrr.07127.

Bhakta JN, Ohnishi K, Munekage Y, Iwasaki K, Wei MQ. 2012. Characterization of lactic acid bacteria-based probiotics as potential heavy metal sorbents. Journal of Applied Microbiology 112, 1193-1206. http://dx.doi.org/10.1111/j.13652672.2012.05284.x.

Ciorba MA, Riehl TE, Rao MS, Moon C, Ee X, Nava GM, Walker MR, Marinshaw JM, Stappenbeck TS, Stenson WF. 2012. Lactobacillus probiotic protects intestinal epithelium from radiation injury in a TLR-2/cyclo-oxygenase2-dependent manner. Gut 61, 829-838. http://dx.doi.org/10.1136/gutjnl-2011300367.

Dahl SG, Allain P, Marie PJ, Mauras Y, Boivin G, Ammann P, Tsouderos Y, Delmas PD, Christiansen C. 2001. Incorporation and distribution of strontium in bone. Bone 28, 446-453. http://dx.doi.org/10.1016/S8756-3282(01)00419-7.

Feord J. 2002. Lactic acid bacteria in a changing legislative environment. Antonie Van Leeuwenhoek 82, 353-360. http://dx.doi.org/10.1023/A:1020648018998.

Fukuda T, Kino Y, Abe Y, Yamashiro H, Kuwahara Y, Nihei H, Sano Y, Irisawa A, Shimura T, Fukumoto M, Shinoda H, Obata Y, Saigusa S, Sekine T, Isogai E. 2013. Distribution of artificial radionuclides in abandoned cattle in the evacuation zone of the Fukushima Daiichi nuclear power plant. PLoS One 8, e54312. http://dx.doi.org/10.1371/journal.pone.0054312.

Halttunen T, Salminen S, Meriluoto J, Tahvonen R, Lertola K. 2008. Reversible surface binding of cadmium and lead by lactic acid and bifidobacteria. International Journal of Food Microbiology 125, 170-175. http://dx.doi.org/10.1016/j.ijfoodmicro.2008.03.041.

Hamada N, Ogino H, Fujimichi Y. 2012. Safety regulations of food and water implemented in the first year following the Fukushima nuclear accident. Journal of Radiation Research 53, 641-671. http://dx.doi.org/10.1093/jrr/rrs032.

Hamada N, Ogino H. 2012. Food safety regulations: what we learned from the Fukushima nuclear accident. Journal of Environmental Radioactivity 111, 83-99. http://dx.doi.org/10.1016/j.jenvrad.2011.08.008.

He LM, Tebo BM. 1998. Surface charge properties of and Cu (II) adsorption by spores of the marine Bacillus sp. strain SG-1. Applied and Environmental Microbiology 64, 1123-1129.

Hirose K. 2012. 2011 Fukushima Dai-ichi nuclear power plant accident: summary of regional radioactive deposition monitoring results. Journal of $\begin{array}{llr}\text { Environmental } & \text { Radioactivity } & 111,17\end{array}$ http://dx.doi.org/10.1016/j.jenvrad.2011.09.003.

Ibrahim F, Halttunen T, Tahvonen R, Salminen S. 2006. Probiotic bacteria as potential detoxification tools: assessing their heavy metal binding isotherms. Canadian Journal of Microbiology 52, 877-885. http://dx.doi.org/10.1139/w06$\underline{043}$.

Kinoshita H, Sohma Y, Ohtake F, Ishida M, Kawai Y, Kitazawa H, Saito T, Kimura K. 2013. Biosorption of heavy metals by lactic acid bacteria and identification of mercury binding protein. Research in Microbiology 164, 701 709. http://dx.doi.org/10.1016/j.resmic.2013.04.004.

Kinoshita N, Sueki K, Sasa K, Kitagawa J, Ikarashi S, Nishimura T, Wong Y, Satou Y, Handa K, Takahashi T, Sato M, Yamagata T. 2011. Assessment of individual radionuclide distributions from the Fukushima nuclear accident covering central-east Japan. Proceedings of the National Academy of Sciences 8, 19526-19529. http://dx.doi.org/10.1073/pnas.1111724108.

Lim BK, Mahendran R, Lee YK, Bay BH. 2002. Chemopreventive effect of Lactobacillus rhamnosus on growth of a subcutaneously implanted bladder cancer cell line in the mouse. Japanese Journal of Cancer Research 93, 36-41. http://dx.doi.org/10.1111/j.1349-7006.2002.tb01198.x.

Merz S, Steinhauser G, Hamada N. 2013. Anthropogenic radionuclides in Japanese food: environmental and legal implications. Environmental Science \& Technology 47, 1248-1256. http://dx.doi.org/10.1021/es3037498.

NAS/NRC (National Academy of Sciences/National Research Council). 2006. Health risks from exposure to low levels of ionizing radiation, BEIR VII, phase 2. National Academy Press 424 p. ISBN 0-309-53040-7.

Nomoto K, Yokokura T, Tsuneoka K, Shikita M. 1991. Radioprotection of mice by a single subcutaneous injection of heat-killed Lactobacillus casei after irradiation. Radiation Research 125, 293-297.

Nzabarushimana E, Miousse IR, Shao L, Chang J, Allen AR, Turner J, Stewart B, Raber J, Koturbash I. 2014. Long-term epigenetic effects of exposure to low doses of 56Fe in the mouse lung. Journal of Radiation Research 55, 823-828. http://dx.doi.org/10.1093/jrr/rru010.

Perdigón G, Maldonado Galdeano C, Valdez JC, Medici M. 2002. Interaction of lactic acid bacteria with the gut immune system. European Journal of Clinical Nutrition 56 Suppl 4, S21-26. http://dx.doi.org/10.1038/sj.ejen.1601658.

Romanenko AM, Ruiz-Saurí A, Morell-Quadreny L, Valencia G, Vozianov AF, Llombart-Bosch A. 2012. Microvessel density is high in clear-cell renal cell carcinomas of Ukrainian patients exposed to chronic persistent low-dose ionizing radiation after the Chernobyl accident. Virchows Archiv 460, 611-619. http://dx.doi.org/10.1007/s00428-012-1243-x. 
Royal HD. 2008. Effects of low level radiation-what's new? Seminars in Nuclear Medicine 38, 392-402. http://dx.doi.org/10.1053/j.semnuclmed.2008.05.006.

Sasaki K, Morikawa H, Kishibe T, Mikami A, Harada T, Ohta M. 2012a Practical removal of radioactivity from sediment mud in a swimming pool in Fukushima, Japan by immobilized photosynthetic bacteria. Bioscience, $\begin{array}{llll}\text { Biotechnology, } \quad \text { and Biochemistry } & 76, & 859-862 .\end{array}$ http://dx.doi.org/10.1271/bbb.110853.

Sasaki K, Morikawa H, Kishibe T, Takeno K, Mikami A, Harada T, Ohta M. 2012b. Practical removal of radioactivity from soil in Fukushima using immobilized photosynthetic bacteria combined with anaerobic digestion and lactic acid fermentation as pre-treatment. Bioscience, Biotechnology, and Biochemistry 76, 1809-1814. http://dx.doi.org/10.1271/bbb.120440.

Schut S, Zauner S, Hampel G, Konig H, Claus H. 2011. Biosorption of copper by wine-relevant lactobacilli. International Journal of Food Microbiology 145, 126131. http://dx.doi.org/10.1016/j.ijfoodmicro.2010.11.039.

Steinhauser G. 2014. Fukushima's forgotten radionuclides: A review of the understudied radioactive emissions. Environmental Science \& Technology. 48, 4649-4663. http://dx.doi.org/10.1021/es405654c.

Steinhauser G, Brandl A, Johnson TE. 2014. Comparison of the Chernobyl and Fukushima nuclear accidents: A review of the environmental impacts. Science of The Total Environment 470-471, 800-817. http://dx.doi.org/10.1016/j.scitotenv.2013.10.029.

Steinhauser G, Schauer V, Shozugawa K. 2013. Concentration of strontium-90 at selected hot spots in Japan. PLoS One 8, e57760. http://dx.doi.org/10.1371/journal.pone.0057760.

Stiles ME, Holzapfel WH. 1997. Lactic acid bacteria of foods and their current taxonomy. International Journal of Food Microbiology 36, 1-29. http://dx.doi.org/10.1016/S0168-1605(96)01233-0.

Taira W, Nohara C, Hiyama A, Otaki JM. 2014. Fukushima's biological impacts The case of the pale grass blue butterfly. Journal of Heredity 105, 710-722. http://dx.doi.org/10.1093/jhered/esu013.

Tokyo Electric Power Company. 2012. Estimation of the released amount of radioactive materials into the atmosphere as a result of the accident in the Fukushima Daiichi Nuclear Power Station. TEPCO press release May 24.

Tsuneoka K, Ishihara H, Dimchev AB, Nomoto K, Yokokura T, Shikita M. 1994. Timing in administration of a heat-killed Lactobacillus casei preparation for radioprotection in mice. Journal of Radiation Research 35, 147-156. http://dx.doi.org/10.1269/jrr.35.147.

Volesky B, May H, Holan ZR. 1993. Cadmium biosorption by Saccharomyces cerevisiae. Biotechnology and Bioengineering 41, 826-829. http://dx.doi.org/10.1002/bit.260410809.

Yamamoto S, Yokoduka T, Fujimoto K, Takagi K, Ono T. 2014. Radiocaesium concentrations in the muscle and eggs of salmonids from Lake Chuzenji, Japan, after the Fukushima fallout. Journal of Fish Biology 84, 1607-1613. http://dx.doi.org/10.1111/jfb.12368.

Yamamoto Y, Poole LB, Hantgan RR, Kamio Y. 2002. An iron-binding protein, Dpr, from Streptococcus mutans prevents iron-dependent hydroxyl radical formation in vitro. Journal of Bacteriology 184, 2931-2939. http://dx.doi.org/10.1128/JB.184.11.2931-2939.2002. 